\title{
Komunikasi Pewarisan Budaya Masyarakat Adat Kampung Mahmud
}

\author{
Vera Hermawan \\ Program Studi Ilmu Komunikasi, Fakultas Ilmu Sosial dan Ilmu Politik \\ Universitas Pasundan \\ Email : vera.hermawan@gmail.com vera.hermawan@unpas.ac.id
}

\begin{abstract}
ABSTRAK
Dalam penelitian ini peneliti mendeskripsikan secara detail proses pewarisan nilai-nilai budaya dari tokoh adat terhadap generasi muda di Kampung Mahmud. Metode penelitian yang digunakan adalah metode penelitian kualitatif, dan metode pendekatan metode studi kasus. Hasil penelitian menunjukan bahwa proses pewarisan tradisi nilainilai budaya dari tokoh adat terhadap generasi muda dalam mengkonstruksi nilai-nilai budaya berdasarkan keyakinan yang kuat terhadap agama Islam sebagai dasar dari tumbuh berkembangnya menjadi budaya yang mewarnai segala aspek kehidupan di Kampung Mahmud. Kepercayaan mereka terhadap keberadaan nenek moyang yang dinamakan karuhun, masih ada sampai dengan sekarang. Masyarakat Kampung Mahmud sekarang lebih dinamis dalam memaknai kehidupannya juga dalam hubungannya dengan masyarakat satu sama lain. Pola komunikasi tokoh adat terhadap generasi muda dalam melestarikan nilai-nilai budaya terjadi dalam dua jenis komunikasi yaitu komunikasi verbal dan komunikasi non-verbal. Interpretasi tokoh adat dan generasi muda dalam memaknai perkembangan zaman terhadap nilai-nilai budaya mengalami perubahan dari fase ke fase. Ini berlangsung secara situasional. Perkembangan teknologi dan perubahan kondisi geografis memaksa untuk menginterpretasikan kembali hal yang tabu menjadi tidak tabu. Secara fisik kehidupan tatanan sosial masyarakat Kampung Mahmud telah berubah karena pengaruh budaya luar, tetapi secara substansi nilai-nilai budaya masih bertahan walaupun zaman terus berkembang.
\end{abstract}

Kata Kunci : Komunikasi Budaya, Masyarakat Adat, Kampung Mahmud 


\section{PENDAHULUAN}

Budaya terlahir sebagai identitas suatu bangsa. Maka persoalan pelestarian budaya menjadi perihal penting. Walaupun pada hakikatnya manusia tidak bisa memilih dan dilahirkan atas ras, agama, atau budaya/etnik. Menjadi hak preogratif Tuhan untuk menciptakan manusia terlahir berasal dari budaya etnik tertentu. Namun terlalu naif jika seseorang yang terlahir atas etnik tertentu tidak mempunyai kesadaran dalam hal melestarikan budaya/etnik dari mana dia berasal. Sebuah dorongan psikologis menjadi hal yang penting dalam pelestarian budaya dimana kita terlahir. Namun bukan berarti mengagung-agungkan atas budaya tertentu, tapi bagaimana kemudian proses pelestarian budaya itu menjadi penting yang sifatnya kontinyu, dan regenerasi kesadaran personal maupun kolektif atas nilai, norma dari budaya tidak berhenti pada titik dimana budaya itu menjadi bias. Menjadi sebuah identitas penting dalam eksistensi manusia bahwa manusia dilahirkan dari budaya yang berbedabeda, sehingga kesadaran personal maupun kolektif-pun harus lahir dalam rangka melestarikan budaya itu, merupakan konsekuensi logis atas perjalanan hidup manusia.

Berangkat dari konsep sederhana, ketika budaya muncul atas kesadaran psikologis sebagai identitas budaya itu sendiri sehingga kesadaran individu maupun kelompok perlu didorong dalam rangka melestarian budaya darimana mereka berasal yang kemudian menjadi identitas-nya pada khususnya, lalu menjadi identitas secara kolektif sebagai bagian dari eksistensi budaya itu sendiri agar budaya itu terus terpelihara dan menjadi bagian dari sebuah identitas bangsa. Penelitian ini berusaha mengurai bagaimana peranan Kampung Mahmud sebagai sistem kebudayaan yang masih terjaga nilainilai budayanya walaupun pengaruh teknologi terus-menerus menghantui dalam tatanan yang sudah terbangun lama dalam pelestarian yang merupakan warisan leluhurnya. Kampung Mahmud menjadi objek penelitian yang kemudian akan diteliti lebih lanjut bagaimana proses regenerasi nilai-nilai budaya itu berlangsung dari tokoh adat ke generasi muda.

Sejarah Kampung Mahmud Eyang Mahmud Abdul Manaf yang merupakan keturunan ke delapan dari Syarif Hidayatuliah seorang wali yang berasal dari Kesultanan Cirebon. Menurut informan sebut saja berinisial SY, menceritakan bahwa:

“...Eyang Dalem Abdul Manaf tos sabaraha lami anjeuna di tanah suci teras anjeuna ka pulau Jawa, nyandak sakeupel taneuh ti guha Mahmud Mekah kanggo ieu tempat, nya mendakan ieu tempat, nya disimpen ku anjeuna di tempat ieu..." (wawancara) 
Terjemahan:

(Eyang Dalem Abdul Manaf sudah berapa lama beliau di tanah suci, terus beliau ke pulau jawa, mengambil sekepal tanah di gua Mahmud Mekah buat tempat disini, disimpan oleh beliau di tempat ini)

Selanjutnya SY menceritakan:

“...sateuacana jenengan Mahmud nya disimpeun sakeupeul ti guha Mahmud Mekah nya, disebatkeun Kampung Mahmud, nyandak jenengan Mahmud Mekah diditu aya..." (wawancara)

Terjemahan:

(...sebelumnya nama Mahmud diambil disimpan segenggam dari gua Mahmud Mekkah, disebutkan Kampung Mahmud diambil dari nama Mahmud darisana)

Dari situ kemudian orang menyebutnya Kampung Mahmud. Selain dari pada itu Kampung Mamud memang kampung yang sangat kental dengan nuansa religius. Berangkat dari sejarah bahwa pendiri Eyang Abdul Manaf dipercayai oleh warga kampung setempat sebagai seorang wali yang menyebarkan agama Islam. Yang menarik adalah bagaimana kemudian proses komunikasi antara generasi ke generasi itu dapat dipelihara dalam konteks menjaga nilai-nilai budaya/adat. Selama ratusan tahun nilai-nilai budaya/adat itu tetap terpelihara, ada banyak hal yang menarik yang kemudian akan digali lebih jauh mengenai proses komunikasi yang sudah terkonstruksi oleh para leluhur di Kampung Mahmud, walaupun belakangan terjadi proses transisi nilai-nilai budaya/adat yang mempengaruhi konstruksi tatanan kehidupan sosial yang selama ini menjadi pantangan yang berlaku di Kampung Mahmud. Tapi dalam konteks kehidupan beragama tidak ada perubahan dan itu senantiasa dijalankan dalam kehidupan keseharian oleh masyarakat Kampung Mahmud.

Artinya nilai-nilai budaya yang berlangsung selama ratusan tahun sebagai warisan dari leluhurnya masih dijalankan. Disisi lain perkembangan zaman dan kondisi geografis telah berubah sehingga telah mempengaruhi pola pikir masyarakat Kampung Mahmud, dan memaksa untuk menginterpretasikan kembali atas apa yang menjadi warisan nilai-nilai budaya leluhur. Banyak diantara konstruksi rumah yang dulu tidak boleh membangun tembok dan kaca, sekarang telah banyak masyarakat yang memakai itu, menggali sumur yang sebelumnya menjadi larangan sekarang tidak menjadi sakral lagi. Banyak makna dan interpretasi dibalik kejadian itu. Artinya telah terjadi transisi nilainilai budaya/adat yang terjadi di Kampung Mahmud dari generasi ke generasi. Perjalanan itulah kemudian yang akan diteliti lebih lanjut.

Dalam konteks lain kehidupan sosial budaya Kampung Mahmud pada 
umumnya tidak jauh berbeda dengan pola kehidupan sosial budaya masyarakat Sunda, khususnya masyarakat Sunda pedesaan di wilayah Kabupaten Bandung. Unsur-unsur ajarannya banyak mewarnai pola kehidupan sosial budaya masyarakatnya. Kehidupan sehari-hari, unsur-unsur tradisi budaya Sunda mewarnai pola kehidupan mereka. Di sini terjadi semacam percampuran budaya antara kedua unsur yang sangat berbeda. Di satu pihak ajaran Islam melekat dengan kental, di pihak lain unsur budaya Sunda mewarnai nuansa kehidupan mereka. Misalnya, tata cara kehidupan yang berkaitan dengan pembangunan rumah, di mana adat Sunda sangat dominan memberikan warna dan nuansanya. Sehingga adanya semacam 'perkawinan' antara kebiasaan adat Sunda tradisional dengan ajaran agama Islam, yang akhirnya lahir Islam yang Nyunda.

Pada konteks ajaran-ajaran moral yang diwariskan oleh leluhur pendiri Kampung Mahmud tidak serta merta ditinggalkan. Walaupun di satu sisi ada perubahan dalam konteks fisik tatanan kehidupan sosial, tetapi dalam ajaran moral dalam hal religi maysarakat Kampung Mahmud masih memegang erat dalam melaksanakan ajaran karuhun yang telah mewarisinya. Banyak acara-acara adat yang disakralkan dan masih dilaksanakan. Artinya disini masyarakat Kampung Mahmud masih mempunyai kesadaran dalam melestarikan budaya leluhur atau karuhun-nya. Ketertarikan untuk melakukan penelitian lebih lanjut pada masyarakat Kampung Mahmud, berusaha mengurai nilai-nilai budaya/adat yang berlaku di Kampung Mahmud serta proses regenerasi budaya itu berlangsung dari tokoh adat ke generasi muda. Interpretasi dari tokoh-tokoh adat dalam memahami adat yang diwariskan karuhun dan menyesuaikan nya dengan kondisi perkembangan jaman. Proses pewarisan nilai-nilai budaya/adat yang masih dipelihara ditengah arus budaya modernisasi yang membiaskan nilainilai budaya/adat sesungguhnya yang mengajarkan ajaran moral dalam kehidupan sehari-hari.

Seperti uraian diatas konstruksi nilainilai budaya diwariskan leluhur untuk menjadi sebuah esensi dari nilai-nilai budaya yang kemudian dilestarikan keberadaannya. Tetapi benturan kemajuan teknologi yang terus berkembang dari berbagai lini kemudian berpengaruh terhadap kelangsungan nilai-nilai budaya yang dijalani. Salahsatunya adalah mengetahui pola dan jenis komunikasi verbal dan non-verbal tokoh adat terhadap generasi muda dalam melestarikan nilai-nilai budaya.

\section{METODE PENELITIAN}

Metode penelitian adalah prosedur yang dilakukan dalam upaya untuk mendapatkan data ataupun informasi 
untuk memperoleh jawaban atas permasalahan penelitian berdasarkan metode kualitatif.. Dengan demikian, penentuan tahapan-tahapan dan teknik yang digunakan harus mencerminkan relevansi dengan realitas yang akan diteliti. Untuk kepentingan ini maka dipilih studi kasus.

Adapun jenis penelitian ini termasuk dalam deskriptif analitis. Dengan demikian terbentuknya objektifitas peneliti untuk memberikan penafsiran atas suatu masalah yang hendak menjadi fokus kajiannya.

Studi kasus merupakan upaya mengumpulkan dan kemudian mengorganisasikan serta menganalisis data tentang kasus-kasus tertentu berkenaan dengan permasalahanpermasalahan yang menjadi perhatian peneliti untuk kemudian data tersebut dibandingkan satu dengan yang lainnya dengan tetap berpegang pada prinsip holistik dan kontekstual (Patton dalam Pawito, 2007:141). Selain itu, menurut Creswell (1998:36) studi kasus adalah sebuah telaahan dari sebuah kasus atau beberapa kasus yang terikat tempat dan waktu dimana sumber informasi didapatkan dari pengumpulan data seperti wawancara, observasi, dokumentasi. Kasus-kasusnya yang diteliti pada studi kasus dapat berupa program, aktivitas, kejadian, dan sekelompok orang (Creswell, 1998:249).

Sebagai suatu metode kualitatif, studi kasus mempunyai beberapa keuntungan. Keistimewaan studi kasus meliputi (Lincoln dan Guba, dalam Mulyana, 2002: 201):

1. Studi kasus merupakan sarana utama bagi penelitian emik, yakni menyajikan pandangan subjek yang diteliti.

2. Studi kasus menyajikan uraian menyeluruh yang mirip dengan apa yang dialami pembaca dalam kehidupan sehari-hari.

3. Studi kasus merupakan sarana efektif untuk menunjukkan hubungan antara peneliti dan responden.

4. Studi kasus memungkinkan pembaca untuk menemukan konsitensi internal yang tidak hanya merupakan konsistensi gaya dan dan konsitensi faktual tetapi juga kepercayaan (trustworthiness).

5. Studi kasus memberikan uraian tebal yang diperlukan bagi penilaian atas transferabilitas.

6. Studi kasus terbuka bagi penilaian atas konteks yang turut berperan bagi pemaknaan atas fenomena dalam konteks tersebut.

Kasus dalam penelitian studi kasus dapat berupa kasus yang sederhana ataupun kasus yang kompleks atau rumit (Stakes dalam Siverman dan Marsvati, 2008: 162-163). Kasus tersebut didasarkan pada apa yang memang sedang ingin diteliti oleh peneliti, berikut tiga fitur analisis dalam penelitian studi kasus (Punch dalam Silverman dan Marsvati, 2008: 163) : 
1. Setiap kasus memiliki batasan yang harus diidentifikasi pada tahap awal penelitian.

2. Setiap kasus merupakan sebuah kasus yang menarik perhatian peneliti. Sehingga unit analisis dapat dijelaskan pada awal penelitian sehingga dapat memperjelas strategi penelitian.

3. Studi kasus digunakan untuk menyajikan keutuhan dan integritas dari kasus yang diteliti. Meskipun demikian, untuk mencapai beberapa fokus dari penelitian, permasalahan penelitian haruslah dibatasi sehingga dapat memperoleh hasil yang spesifik.

Dalam studi kasus terdapat beberapa jenis studi kasus, yaitu penelitian yang berdasarkan satu kasus saja dan penelitian yang berdasarkan dari beberapa kasus. Studi kasus dalam penelitian komunikasi, meski sering memusatkan perhatian pada satu kasus tunggal, kenyataannya dapat pula melibatkan beberapa kasus yang diteliti (Pawito, 2007:144).

Dalam penelitian ini menggunakan penelitian studi kasus mendalam (intrinsic case study). Memusatkan penelitian dalam satu kasus saja, pemilihan metode ini dimaksudkan untuk menggali hal-hal mendasar di balik kasus yang menjadi fokus penelitian yaitu menggali proses pewarisan nilai budaya dari tokoh adat ke generasi muda di Kampung Mahmud Kabupaten Bandung.
Subjek penelitian dari penelitian ini adalah tokoh adat dan generasi muda di Kampung Mahmud Bandung. Tokoh adat dan generasi muda yang dijadikan subjek dari penelitian ini adalah dua tokoh adat dan satu generasi muda. Dua tokoh adat ini yang berpengaruh terhadap kelangsungan nilai-nilai adat yang dipelihara sejak lama dari leluhurnya, sedangkan satu generasi muda sebagai mata rantai dalam melestarikan nilai-nilai adat yang diajarkan oleh tokoh-tokoh adat. Subjek penelitian yang merupakan informan dalam penelitian ini dipilih dengan menggunakan tehnik purposive sampling dengan bedasarkan kriteriakriteria tertentu. Kriteriakriteria yang digunakan dalam pemilihan narasumber adalah orang yang mempunyai pengaruh yang besar di Kampung Mahmud dalam menjalani nilai budaya dan tradisi setempat yaitu dua orang tokoh adat dan satu orang generasi muda sebagai penerusnya. Semua berdomisili di Kampung Mahmud Bandung.

Sementara itu, Objek Penelitian itu adalah bagaimana proses komunikasi antara tokoh adat terhadap generasi muda dalam mewarisi nilai-nilai budaya yang merupakan warisan dari para leluhurnya di Kampung Mahmud. Menggali pengetahuan, pemahaman tokoh adat dalam mengkonstruksi nilainilai budaya. menganalisa pola komunikasi tokoh adat terhadap generasi muda dalam melestarikan nilai-nilai budaya. Mencari tahu proses 
interpretasi tokoh adat dalam
memaknai
terhadap kerkembangan
budaya.

\section{PEMBAHASAN}

Kehidupan sosial di Kampung Mahmud secara umum tidak jauh berbeda dengan kehidupan sosial masyarakat Sunda, khususnya masyarakat Sunda pedesaan di wilayah Kabupaten Bandung. Posisi Kampung Mahmud terletak di desa Mekarrahayu, Kecamatan Margaasih, Kabupaten Bandung Populasi masyarakat Kampung Mahmud sekitar 2000 orang dan terbagi dalam empat RT. Warga Kampung Mahmud mempunyai latar belakang sejarah yang berbeda dengan kampung lainnya, yang beranggapan bahwa Kampung Mahmud merupakan cikal bakal masyarakat di sekitarnya yang berasal dari keturunan Sembah Eyang Abdul Manaf sebagai penyebar ajaran Islam. Seiring dengan berjalannya waktu Kampung Mahmud menjadi kampung yang sangat kental dengan nuansa religius. Karena berangkat dari sejarah bahwa pendiri Eyang Abdul Manaf dipercayai oleh warga kampung setempat sebagai seorang wali yang menyebarkan agama Islam. Ini sejalan dengan apa yang dituturkan oleh SY, mengatakan bahwa:

"jadi ieumah seolah-olah hukum adat karuhun, wali, ceuk para waliyulloh mah tasawuf, tawadho, geus ma'rifat ka Alloh geus teu mikirkeun masalah dunya, akherat sareng Alloh wé..." (wawancara)

Terjemahan:

(jadi ini seolah-olah hukum adat leluhur, wali, kata para walliyullah disebut tasawuf, tawadho, sudah ma'rifat sama Alloh sudah tidak memikirkan duniawi, masalah akhirat mengingat Alloh saja)

Selanjutnya SY mengatakan:

“...tuluy diamanatkeun ka anak incuna sakieu amanatna, kadé mihapé anak incu kami, shalat jeung ngaji... sakitu. Jeung deui di Kampung Mahmud teu rido teu ngawidian ngabogaan sifat riya..." (wawancara)

Terjemahan:

(...terus diamanatkan ke anak cucu segini amanatnya, jangan lupa anak cucu kami, shalat dan ngaji... segitu, terus di Kampung Mahmud tidak ridho dan tidak mengijinkan mempunyai sifat riya...)

Jadi karuhun di Kampung Mahmud sudah mengkonstruksi apa yang menjadi keyakinannya untuk diteruskan terhadap generasi selanjutnya dengan cara penyampaian baik itu secara verbal ataupun nonverbal. Secara verbal beliau mengatakan secara lugas memberikan petuah kepada keturunannya bahwa apa yang diyakininya kebenaran agama islam yang menjadi pegangan dalam kehidupan sehari-hari harus senantiasa dipegang teguh, yaitu shalat lima waktu 
dan senantiasa membaca Al-Quran sebagai tuntunan hidup, dan menjauhi sikap riya, menjauhi kehidupan duniawi dan mencari kehidupan akhirat. Secara no-verbal beliau menunjukan dengan sikap yang dikagumi sehingga para penerusnya secara tidak langsung tunduk dan patuh terhadap apa yang diperintahkan dan apa yang menjadi petuah yang dituangkan dalam aturan tidak tertulis yang ada di Kampung Mahmud.

Ajaran itu yang kemudian menjadi budaya di masyarakat Kampung Mahmud taat dalam menjalankan kehidupan beragama dalam kesehariannya. Selain itu juga banyak hal yang menjadikan Kampung Mahmud ini unik dengan adanya beberapa pantangan yang berlaku di Kampung mahmud. Seperti apa yang dikatakan oleh RO, yaitu:

“...di Mahmud mah teu kenging ngadamel bumi tembok, teu kenging ngukut angsa, teu kenging mukul goong, teu kengiung aya wayang, teu kenging ngaemam hulu hayam, teu kenging ngadamel sumur..." (wawancara)

Terjemahan :

(di Kampung Mahmud tidak boleh mendirikan bangunan rumah dengan tembok, tidak boleh memukul goong, tidak boleh ada wayang, tidak boleh memakan kepala ayam, tidak boleh membuat sumur)
Banyak makna yang terkandung dari beberapa larangan itu. Larangan itu sebetulnya berkaitan dengan sejarah adanya Kampung Mahmud dan kondisi geografisnya dapat dijelaskan secara ilmiah dengan adanya aturan-aturan itu pendiri Kampung Mahmud sebetulnya telah mengkonstruksi aturan-aturan yang tidak tertulis yang berlaku untuk masyarakat Kampung Mahmud. Aturan itu berupa larangan-larangan atau pantangan yang tidak boleh dilakukan oleh masyarakat dalam menjalankan kehidupan keseharian. Seperti; tidak boleh membangun rumah dengan material tembok dan kaca, tidak boleh membunyikan goong, tidak boleh menggali sumur, tidak boleh menanggap wayang, dan lain-lain. Dibalik itu semua mungkin saja terkandung makna yang bisa dijelaskan secara ilmiah. Karena menurut sejarah Kampung Mahmud adalah tempat persembunyian yang tidak terjamah oleh penjajah Belanda. Jadi hal-hal yang menarik perhatian dan menimbulkan bunyi yang keras dilarang di Kampung itu.

Tetapi pada perkembangannya setelah kondisi negara terbentuk dan merdeka kepercayaan itu masih diyakini masyarakat sebagai pantangan atau titah para leluhurnya yang dilakukan sampain dengan sekarang. Bila masyarakat melanggarnya maka diyakini masyarakat akan terjadi musibah kepada yang melanggar aturan adat itu. 
Penelitian ini juga berusaha mengurai bagaimana proses komunikasi tokoh adat terhadap generasi muda dalam melestarikan adat yang terjadi di Kampung Mahmud dalam melestarikan budaya dengan besarnya gesekan pengaruh teknologi yang begitu kuat. Serta bagaimana kemampuan konstruksi yang dibangun oleh pendiri Kampung Mahmud dapat secara kontinyu dilakukan oleh masyarakat Kampung Mahmud selama ratusan tahun lamanya. Penelitian ini juga mengurai apa yang telah berubah dalam kondisi sosial budaya di Kampung Mahmud. Pola komunikasi tokoh adat terhadap generasi muda menjadi poin penting.

Dalam penelitian ini memakai dua teori yaitu teori konstruksi sosial atas realitas dan teori interaksi simbolik sebagai pisau analisa dalam mengupas fenomena budaya yang terjadi di Kampung Mahmud.

Berangkat dari pemahaman Berger dan Luckmann (1966: 66) mengenai teori konstruksi sosial atas realitas mengatakan bahwa terjadi dialektika antara individu menciptakan masyarakat dan masyarakat menciptakan individu. Proses dialektika ini terjadi melalui eksternalisasi, objektivasi, dan internalisasi.

Pertama, eksternalisasi (penyesuaian diri) dengan dunia sosiokultural sebagai produk manusia. Kedua, objektivasi, yaitu interaksi sosial yang terjadi dalam dunia intersubjektif yang dilembagakan atau mengalami proses institusionalisasi. Sedangkan ketiga, internalisasi, yaitu proses dimana individu mengidentifikasikan dirinya dengan lembaga-lembaga sosial atau organisasi sosial tempat individu menjadi anggotanya.

Dalam penelitian ini eksternalisasi terjadi ketika pendiri Kampung Mahmud berusaha dengan kondisi sosiokultural yang berlaku pada saat itu akhirnya menyesuaikan diri terhadap apa yang dipahaminya mengenai ajaran-ajaran hidup dalam memahami agama islam. Berangkat dari pemahamannya itu kemudian beliau berusaha menyesuaikan dengan kondisi geografis serta menciptakan tatanan sosial yang dipahaminya ideal dalam melanjutkan kelangsungan hidup di kemudian hari. Karena kemudian pengaruhnya begitu besar di Kampung Mahmud maka objektivasi itu berlaku pada masyarakat yang akhirnya sepakat bahwa apa yang dipahami pendiri Kampung Mahmud mengajarkan ajaran-ajaran hidup yang serta merta membawa pada kehidupan yang lebih baik. Dari proses itulah kemudian terjadi pensakralan ajaran yang berawal dari konstruksi pemahaman individu kemudian dilembagakan menjadi pemahaman yang institusional karena secara hierarki itu berlaku (objektivasi), karena ajaran-ajaran moral itu kemudian membentuk ketokohan yang sangat berpengaruh dalam kehidupan masyarakat, dan ketokohan itu 
kemudian terus berkembang sebagai pemegang sakralisasi ajaran yang diwariskan dari generasi ke generasi.

Pada akhirnya ajaran-ajaran moral itu mempunyai makna baik itu secara simbolik yang secara tidak langsung mengikat anggota masyarakatnya untuk menjadi bagian dan menaati serta berkewajiban untuk melestarikan ajaran moral yang di ajarkan karuhun untuk senantiasa dipegang teguh sebagai pedoman hidup anggota masyarakat itu (internalisasi).

Perjalanan ide, pengetahuan, serta pemahaman pendiri Kampung Mahmud sehingga membentuk sebuah kelompok masyarakat dengan aturan adat yang sakral tentu mengalami proses yang panjang dan aturan adat itu berlaku lama memakan waktu ratusan tahun lamanya.

Dalam teori Interaksi Sombolik pada intinya menjelaskan tentang kerangka untuk memahami bagaimana manusia melakukan interaksi bersama dengan bersama manusia lainnya dalam melakukan aktifitas keseharian, menciptakan dunia simbolik dan bagaimana cara dunia membentuk perilaku manusia. Interaksi simbolik ada karena ide-ide dasar dalam membentuk makna yang berasal dari pikiran manusia (Mind) mengenai diri (Self), dan hubungannya di tengah interaksi sosial, dan tujuan bertujuan akhir untuk memediasi, serta menginterpretasi makna di tengah masyarakat (Society) dimana individu tersebut menetap. Seperti yang dicatat oleh Douglas (1970) dalam Ardianto (2007: 136), Makna itu berasal dari interaksi, dan tidak ada cara lain untuk membentuk makna, selain dengan membangun hubungan dengan individu lain melalui interaksi.

Dalam penelitian ini, ide dasar ajaran karuhun yang berlaku di Kampung Mahmud berasal dari pendiri Kampung Mahmud tentang pengetahuannya yang bersumber dari agama Islam. Kemudian menjadi pengetahuan dasar sehingga dipahami oleh penerusnya menjadi sebuah kesadaran dalam menjaga dan mewarisi tradisi ajaran karuhun dari generasi ke generasi. Tokoh adat dan generasi muda di Kampung Mahmud menyadari betul kondisi tatanan sosial di tempat tinggalnya telah memiliki hukum adat dan ajaran sosial yang sakral, sehingga secara sadar dan spontan tokoh adat dan generasi muda serta masyarakat Kampung Mahmud berada dalam kondisi situasional itu (mind).

Adanya interpretasi melihat dunia dan perkembangan jaman seperti yang telah diuraikan diatas, pertama, tokoh adat pada masa H.Amin melakukan terobosan dalam menggali sumur sebagai sumber air karena sumber air dari sungai citarum sudah tercemar oleh limbah pabrik, interpretasi terhadap hukum adat yang berlaku di Kampung Mahmud ini berpengaruh terhadap generasi selanjutnya. Kedua, tokoh adat sekarang telah mengijinkan adanya 
kontruksi bangunan dengan material tembok dan kaca, karena perkembangan geografis tanah yang asalnya tanah rawa dengan kondisi yang labil sekarang sudah mengeras dan kuat, sehingga memungkinkan untuk bisa membangun bangunan dengan material tembok dan kaca (material berat). Artinya tokoh adat dan generasi muda sekarang telah menggunakan pikiran (rasionalisasi) dalam memahami dunia dan perkembangan jaman, ini dilakukan dalam usaha untuk melangsungkan kehidupan dan hak untuk memperoleh kehidupan yang layak.

Dalam memahami dirinya tokoh adat dan generasi muda tentu tidak dapat lepas apa yang mendahuluinya yaitu berawal dari proses mind yang telah diuraikan diatas. Pengetahuan dan pemahaman yang terbentuk secara situasional, menjadikan tokoh adat dan generasi muda Kampung Mahmud sebagai individu-individu yang secara tidak langsung mempunyai kewajiban dalam mewarisi budaya karuhun atau leluhurnya (self).

Perkembangan jaman dan perubahan tatanan sosial yang dialaminya secara sadar memaksa tokoh adat dan generasi muda Kampung Mahmud untuk terus bisa menginisiasi demi keberlangsungan hidup dan memahami dunia luarnya. Tanpa meninggalkan benang merah ajaran karuhun yang secara substansi mengajarkan ajaran- ajaran moral yang bersumber dari agama Islam.

Dalam kondisi tatanan kehidupan sosial masyarakat yang membentuk individuindividu secara situasional secara sadar menjadikan tokoh adat dan generasi muda Kampung Mahmud berusaha untuk menjaga ajaran-ajaran karuhun secara substansi, tetapi juga berusaha untuk menginterpretasikan kembali dalam menyikapi perkembangan jaman. Ini bertujuan untuk melanjutkan keberlangsungan hidupnya. Saling berinteraksi satu sama lain, melakukan berbagai aktivitas pendukung kehidupan bersama dalam menjalankan kehidupan sosial masyarakat. Berinteraksi dengan masyarakat luar, bahkan Kampung Mahmud ini sekarang telah dijadikan kampung wisata religi. Dengan banyaknya orang masuk dan lalu lalang melakukan ziarah ke makom dan melakukan aktifitas-aktifitas keagamaan seperti pengajian rutin dan menghadiri acaraacara besar di Kampung Mahmud. Artinya bahwa masyarakat Kampung Mahmud dalam situasional hari ini cenderung lebih terbuka dalam berinteraksi dengan masyarakat lainnya. Tidak serta merta menolak budaya yang dibawa masyarakat lain ke Kampung Mahmud, tetapi dengan cara menginisiasinya jika itu tidak melanggar substansi ajaran-ajaran dari karuhunnya, tidak keluar dari ajaran agama Islam, juga budaya itu mempunyai banyak manfaatnya yang dapat digunakan dalam kehidupan 
sehari-hari oleh masyarakat Kampung Mahmud (society).

\section{Pola dan jenis komunikasi tokoh adat terhadap generasi muda dalam melestarikan nilai-nilai budaya.}

Dalam penelitian ini peneliti mengurai proses komunikasi berdasarkan modelmodel yang telah menjadi dasar dalam pembelajaran ilmu komunikasi. Berangkat dari model komunikasi lasswell melalui model who, says what, in which channel, to whom, with what effect untuk mengurai bagaimana proses komunikasi ini berlangsung dari tokoh adat ke generasi muda terkait pewarisan nilai-nilai budaya. Peneliti berusaha mengurai pewarisan budaya dari tokoh adat ke generasi muda sebagai proses. Penggunaan komunikasi verbal dan non-verbal melalui tindakan, ataupun simbolsimbol komunikasi yang yang terjadi di Kampung Mahmud. Budaya yang telah terbentuk diuraikan dalam proses pewarisan nilai-nilai budaya melalui proses komunikasi sehingga merangsang respon baik berpengaruh terhadap pengetahuan dan pemahaman tokoh adat dalam memahami nilai-nilai budaya sebagai warisan leluhur ataupun cara merangsang kembali kesadaran keberlangsungan nilai-nilai budaya yang telah berlaku di Kampung Mahmud terhadap generasi muda.

Berangkat dari model lasswell proses pewarisan budaya dilakukan oleh tokoh adat (who), mengajari dan mengatakan apa yang dipahami tokoh adat mengenai pentingnya nilai-nilai budaya yang telah terbentuk dalam bentuk komunikasi verbal dan non-verbal (say what), melalui media komunikasi dalam interaksi secara langsung (in which channel), proses komunikasi ini disampaikan kepada masyarakat untuk mengingatkan betapa pentingnya nilainilai budaya ini dijaga dan dilestarikan sebagai warisan dari karuhun dan juga termasuk generasi muda Kampung Mahmud sebagai penerus keberlangsungan nilai-nilai budaya (in which channel), dan terakhir masyarakat dan generasi muda di kampung mahmud secara sadar akan pentingnya menjaga dan mewariskan nilai-nilai budaya yang telah terkonstruksi secara situasional yang disampaikan terus-menerus oleh tokoh adat melalui komunikasi verbal dan non-verbal, ataupun pengetahuan masyarakat berdasarkan history tentang Kampung Mahmud sebagai kampung adat yang memegang teguh ajaran tentang nilai sebagai warisan dari karuhun yang harus dijaga dan dilestarikan keberadaannya walaupun pemahaman ini dipahami oleh masyarakat dan generasi muda mempunyai interpretasi lain dalam beberapa hal, memahami nilai-nilai dalam konteks pewarisan nilai-nilai budaya (with what effect).

Kampung Mahmud dalam mewarisi budaya karuhun berangkat dari apa yang dipahaminya yang secara 
langsung ataupun tidak, telah mempengaruhi pemahaman, pengetahuan tokoh adat sebagai warisan dari karuhun. Dalam pendekatan model ini tokoh adat melakukan dua jenis komunikasi, yaitu; komunikasi verbal dan non-verbal.

Pertama, komunikasi verbal dengan cara mengingatkan masyarakat dan generasi muda dalam pengajian rutin dan juga setelah shalat magrib, juga menggunakan momentum acara-acara besar adat untuk memperlihatkan bahwa apa yang diajarkan oleh karuhun masih berlaku. Disisi lain juga ajaran agama islam sebagai benang merah dari ajaran karuhun sangat kental dan menjadi inti dari ajaran-ajaran moral yang diajarkan oleh karuhun di Kampung Mahmud. Seperti yang dikatakan RO, mengatakan bahwa:

“...jelas atuh ari etamah da dina pangajian sepuh ge pan ngomentar, ka anak-anak muda saleresna tos pada apal ajaran-ajaran nu diajarkeun sesepuh teh dina hal agama kedah jadi pegangan..." (wawancara)

Terjemahan:

(jelas kalau itu dari pengajian orang tua juga mengomentar, ke anak-anak muda sebetulnya sudah pada tahu ajaranajaran yang diajarkan oleh leluhur dari hal agama harus jadi pegangan)

Jadi ajaran karuhun dalam hal agama islam telah melekat kuat dimasyarakat dan ajaran itu senantiasa dilakukan secara kontinyu sebagai keberlangsungannya nilai-nilai budaya yang berlaku di Kampung Mahmud. Masyarakat Kampung Mahmud dan Generasi mudanya telah menyadari tentang ajaran yang diajarkan oleh karuhun itu harus senantiasa berlanjut secara estafet tanpa terputus, sebagai penghargaan atas nilai-nilai budaya/adat, juga generasi muda berperan aktif dalam mewariskan nilainilai budaya leluhurnya secara kontinyu.

Kedua, komunikasi non-verbal dilakukan dalam mewariskan budaya karuhun dari tokoh adat ke generasi muda. Seperti yang dikatakan RO; “...janten boh secara lisan boh tina sikap sesepuh saleresna an

ak-anak muda teh teu dipeupeujeuhkeun deui ge tos sadar sendiri lah...". Ini menandai bahwa tokoh adat mengajarkan kepada generasi muda sebagai penerus senantiasa ditunjukan dengan sikap dan perilaku-nya dalam kehidupan seharihari.

Selanjutna RO mengatakan:

“...teras tina segi lingkungan sapertos acara keagamaan eta saleresna tos spontan...", dari sini jelas menandakan bahwa sikap dan perilaku tokoh adat terhadap generasi muda serta masyarakat Kampung Mahmud telah mengetahui dan sadar untuk menjalankan apa yang diwariskan karuhun dalam menjalankan perintah agama Islam yang kemudian yang 
menjadi nilai-nilai budaya/adat yang berkembang di Kampung Mahmud.

Proses interaksi yang dilakukan oleh tokoh adat terhadap generasi muda dalam mewariskan nilai-nilai budaya karuhun dengan cara yang telah terbentuk situasional nilai-nilai budaya/adat di Kampung Mahmud. Selain efektif cara ini juga sebenarnya secara tidak sadar telah mengkonstruksi generasi muda dan mayarakat Kampung Mahmud untuk senantiasa menjalankan apa yang telah dijalankan karuhun atau leluhurnya. SY mengatakan bahwa:

“...ajaran mah pokonamah pangaosan we, patin muludan 12 mulud, rajaban 27 rajab memperemut Isra Mi'raj, khaol-khaolan eyang minggu kadua saba'da Iedul Fitri di makom. Pasuroan 10 muharam, tolak bala, rebo kasan, rebo terakhir bulan sabat. Aya keneh didieumah, sakumaha terusterus ti luhurna we, teu dipiceun, terutami pangaosan..." (wawancara)

Terjemahan:

(ajaran yang jelas pengajian aja, patinan, muludan 12 mulud, rajaban 27 rajab, mengingat Isra Mi'raj, khaolkhaolan eyang minggu kedua setelah Idul Fitri di makam. Pasuroan 10 muharam, tolak bala rebo kasan, rabu terakhir bulan sabat. Masih ada disini, apa yang diajarkan leluhur, belum dibuang, terutama pengajian)

Jadi momentum yang paling efektif untuk mewarisi nilai-nilai budaya karuhun dari tokoh adat terhadap generasi muda yaitu mengajarkannya dalam memperingati acara-acara besar adat dalam hal yang berkaitan dengan keagamaan. Proses interaksi ini secara sadar ataupun tidak telah membentuk pola pikir generasi muda untuk terus menjaga dan menjalankan apa yang telah dijalani karuhun atau leluhurnya. Karena ini seperti amanat yang diberikan leluhur agar nilai-nilai budaya di Kampung Mahmud tidak hilang ditelan jaman, dan pewarisan nilai-nilai budaya ini disadari betul oleh generasi muda untuk terus menjalankannya.

\section{Jenis komunikasi verbal dan non- verbal tokoh adat terhadap generasi muda dan masyarakat Kampung Mahmud}

\section{Komunikasi Verbal}

1. Dalam pengajian rutin selepas shalat magrib tokoh adat/sesepuh selalu berkomentar akan pentingnya melestarikan adat warisan karuhun.

2. Dalam acara-acara besar adat seperti patin muludan 12 mulud, rajaban 27 rajab memperingati Isra Mi'raj, khaol-khaolan eyang minggu kedua setelah Iedul Fitri di makom karuhun, tokoh adat/sesepuh menggunakan acara-acara besar adat sebagai momentum efektif menunjukan kepada generasi muda tentang pentingnya melestarikan adat karuhun. 


\section{Komunikasi Non-verbal}

1. Sikap konsisten tokoh adat/sesepuh dalam menjalankan aturan adat terutama yang paling mendasar dalam hal ajaran religi sebagai warisan karuhun ditunjukan dalam kehidupan sehari-hari.

2. Aturan adat warisan karuhun secara langsung telah mengikat generasi muda dan

Generasi Muda dan Mayarakat Kampung Mahmud.

Generasi muda dan masyarakat secara sadar dan spontan memahami aturan adat warisan karuhun sebagai sesuatu yang sakral dan menjalankannya dalam kehidupan sehari-hari.

\section{Analisa Budaya Kampung Mahmud Menuju Transisi Masyarakat Modern}

Seperti yang telah dibahas sebelumnya budaya Kampung Mahmud memang masih bersifat tradisional, adat istiadat masih berlaku merupakan hasil dari konstruksi pemahaman, pengetahuan dan ide pendiri Kampung Mahmud. Dalam perkembangannya itu situasi Kampung Mahmud tidaklah statis, kondisi sosial budaya Kampung Mahmud senantiasa berubah seiring dengan perkembangan zaman. Dalam perilaku kehidupan keseharian, masyarakat telah mengalami perubahan dari yang sifatnya tradisional menjadi masyarakat yang modern. Terjadi semacam transisi budaya, melalui fase ini walaupun sebetulnya belum menjadi masyarakat yang modern seutuhnya. Tetapi benturan budaya modernitas berusaha membuat budaya yang telah terbentuk dalam aturan keseharian Kampung Mahmud menjadi bias, seperti dalam penggunaan teknologi, perkembangan pola pikir, kehidupan ekonomi dan pola home industri yang mendekati cir-ciri menuju masyarakat modern. Ciri-ciri itu telah masuk sebagai pengaruh dari perilaku masyarakat modern dalam menjalankan kehidupan keseharian.

Jika dilihat dari kondisi geografis, Kampung Mahmud memang sangat dekat dengan kawasan industri tekstil Cigondewah, mungkin hanya berjarak 2-3 km dari Kampung Mahmud. Ini menandakan bahwa begitu dekatnya Kampung Mahmud dengan kehidupan masyarakat modern yang berada di Cigondewah. Kondisi ini menyebabkan pola pikir masyarakat Kampung Mahmud mengalami perubahan. Maka dalam kehidupan kesehariannya pun masyarakat Kampung Mahmud mengalami perubahan menuju masyarakat modern walaupun secara substansial ajaran adat karuhun masih berlaku di masyarakat Kampung Mahmud. Perubahan kondisi sosial budaya ini yang kemudian disebut dengan masa transisi masyarakat Kampung Mahmud dari masyarakat tradisional menuju masyarakat modern. 
Teknologi, masuknya teknologi ke Kampung Mahmud merupakan ciri transisi masyarakat ini menuju masyarakat modern. Alat-alat komunikasi, televisi sebagai ciri yang nyata bahwa teknologi sudah mulai masuk sebagai penunjang informasi dalam menjalankan kehidupan keseharian mereka. Dalam tahap ini Kampung Mahmud telah memasuki jendela baru dalam memahami dunia di luar mereka, yang sebelumnya tidak boleh ada di Kampung Mahmud.

Pola pikir, titik awal perubahan pola pikir itu bermula ketika kondisi geografis di Kampung Mahmud berubah ketika sungai yang menjadi sumber air yang penting telah tercemar oleh limbah yang menyebabkan air sungai menjadi kotor, dan menyebabkan tokoh adat di Kampung Mahmud membolehkan untuk menggali sumur sebagai pengganti sumber air bagi masyarakat Kampung Mahmud, terjadi interpretasi dalam memaknai kehidupan keseharian sebagai usaha untuk mempertahankan hidup. Selain itu juga pembangunan jembatan yang memudahkan Kampung Mahmud dengan Cigondewah menjadi terbuka aksesnya. Dari situ kemudian terjadi interaksi antara masyarakat Kampung Mahmud dengan masyarakat Cigondewah yang telah modern, proses ini membuat pola pikir masyarakat Kampung Mahmud banyak terpengaruhi dengan tatanan kehidupan modern Masyarakat Cigondewah, kita mengenal kawasan Cigondewah adalah kawasan industri dan kawasan industri merupakan ciri dari masyarakat modern. Masuknya alat komunikasi dan televisi menambah benang merah masyarakat Kampung Mahmud sebagai masyarakat transisi menuju masyarakat modern yang pola pikirnya mulai terbuka dalam memahami dan memaknai kehidupan keseharian. Artinya jelas bahwa nilai-nilai budaya yang terjadi di Kampung Mahmud telah banyak terpengaruh terhadap perkembangan teknologi.

Kehidupan ekonomi, Dalam menjalankan kehidupannya masyarakat Kampung Mahmud yang kekinian mengenal cara bagaimana menghasilkan dan memutarkan uang dalam aktifitas ekonomi sebagai usaha untuk mempertahankan hidup. Ini terlihat dari banyak dari Masyarakat Kampung Mahmud yang berdagang membuka warung, berbisnis kayu mebel sebagai mata pencaharian mereka. Tetapi juga banyak yang masih tradisional bertani dan bercocok tanam sebagai aktifitas ekonomi dan keseharian mereka. Yang paling menonjol adalah banyak generasi muda Kampung Mahmud yang bekerja di luar Kampung, kita tahu bahwa kerja adalah budayanya masyarakat modern, sehingga dalam kondisi seperti ini Kampung Mahmud telah memasuki era baru sebagai masyarakat transisi menuju masyarakat modern.

Industri rumahan, tidak banyak anggota dari masyarakat Kampung Mahmud 
menjalankan industri rumahan. Tapi ada beberapa orang yang bergulat di dunia kayu mebel, walaupun dari proses pengerjaannya masih terbilang sederhana tapi industri rumahan inilah yang semakin menguatkan Kampung Mahmud sebagai ciri transisi menuju masyarakat modern.

Proses transisi budaya masyarakat Kampung Mahmud menuju masyarakat modern terjadi sebagai ekses dari benturan modernitas. Interpretasi tokoh adat mempengaruhi pola pikir masyarakat dalam memaknai kehidupannya terhadap keadaan geografis yang berubah, ini berlangsung secara situasional. Perkembangan teknologi dan perubahan kondisi geografis memaksa untuk menginterpretasikan kembali hal yang tabu menjadi tidak tabu. Tapi dalam pandangan lain sebetulnya ada yang tidak berubah dalam tatanan budaya di Kampung Mahmud yaitu secara substansi nilai-nilai budaya/adat masih terus berjalan walaupun jaman terus berkembang walaupun secara fisik kehidupan tatanan sosial masyarakat Kampung Mahmud telah berubah.

\section{SIMPULAN}

Budaya Kampung Mahmud memang masih bersifat tradisional, adat istiadat masih berlaku merupakan hasil dari konstruksi pemahaman, pengetahuan dan ide pendiri Kampung Mahmud. Dalam perkembangannya itu situasi Kampung Mahmud tidaklah statis, kondisi sosial budaya Kampung
Mahmud senantiasa berubah seiring dengan perkembangan zaman. Dalam perilaku kehidupan keseharian, masyarakat telah mengalami perubahan dari yang sifatnya tradisional menjadi masyarakat yang modern. Terjadi semacam transisi budaya, melalui fase ini walaupun sebetulnya belum menjadi masyarakat yang modern seutuhnya. Tetapi benturan budaya modernitas berusaha membuat budaya yang telah terbentuk dalam aturan keseharian Kampung Mahmud menjadi bias, seperti dalam penggunaan teknologi, perkembangan pola pikir, kehidupan ekonomi dan pola home industri yang mendekati cir-ciri menuju masyarakat modern. Ciri-ciri itu telah masuk sebagai pengaruh dari perilaku masyarakat modern dalam menjalankan kehidupan keseharian.

Pada akhirnya ajaran-ajaran moral itu mempunyai makna baik itu secara simbolik yang secara tidak langsung mengikat anggota masyarakatnya untuk menjadi bagian dan menaati serta berkewajiban untuk melestarikan ajaran moral yang di ajarkan karuhun untuk senantiasa dipegang teguh sebagai pedoman hidup anggota masyarakat itu (internalisasi).

Proses transisi budaya masyarakat Kampung Mahmud menuju masyarakat modern terjadi sebagai ekses dari benturan modernitas. Interpretasi tokoh adat mempengaruhi pola pikir masyarakat dalam memaknai kehidupannya terhadap keadaan geografis yang berubah, ini berlangsung secara situasional.

Budaya Kampung Mahmud memang masih bersifat tradisional, adat istiadat masih berlaku merupakan hasil dari 
konstruksi pemahaman, pengetahuan dan ide pendiri Kampung Mahmud. Dalam perkembangannya itu situasi Kampung Mahmud tidaklah statis, kondisi sosial budaya Kampung Mahmud senantiasa berubah seiring dengan perkembangan zaman. Dalam perilaku kehidupan keseharian, masyarakat telah mengalami perubahan dari yang sifatnya tradisional menjadi masyarakat yang modern. Terjadi semacam transisi budaya, melalui fase ini walaupun sebetulnya belum menjadi masyarakat yang modern seutuhnya.

Konstruksi nilai-nilai budaya diwariskan leluhur untuk menjadi sebuah esensi dari nilai-nilai budaya yang kemudian dilestarikan keberadaannya. Tetapi benturan kemajuan teknologi yang terus berkembang dari berbagai lini kemudian berpengaruh terhadap kelangsungan nilai-nilai budaya yang dijalani.

\section{DAFTAR PUSTAKA}

Ardianto, Elvinaro \& Bambang QAnees. Filsafat Ilmu Komunikasi. Simbiosa Rekatama Media. 2007.

Dinas Kebudayaan dan Pariwisata Propinsi Jawa Barat. Kampung Adat dan Rumah Adat Di Jawa Barat. 2002.

Gaus, F. Gerald \& Chandran Kukhatas. Handbook Teori Politik. Nusa Media: Bandung. 2012.

Gorman, Robert A. Dual Vision. London: Routledge and Kegan Paul. Ltd. 1977.
Hardiman, F. Budi. Menuju Masyarakat Komunikatif. Kanisius: Yogyakarta. 2009.

Hardiman, F. Budi. Robertus Robet. A. Setyo Wibowo. Thomas Hidya Utama. Empat Essai Etika Politik. Www.srimulyani.net: Jakarta. 2011.

Haryoto Kunto. Wajah Bandoeng Tempo Doeloe. Bandung : Granesia. 1984.

Hurrserl, Edmund. Ideas: General Introduction to The Pure Phenomenology. United State of America: Collier Books Edition. 1962.

Jakob Sumardjo. Arkeologi Budaya Indonesia Pelacakan Hermeneutis - Historis terhadap Artefak - artefak Kebudayaan Indonesia. Yogyakarta: Qalam. 2002.

Koentjaraningrat. Manusia dan Kebudayaan Di Indonesia. Jakarta: Djambatan. 2002.

Littlejhon, Stephen W. Theories of Communication Studies. California Wardworth Publising Company. 1999.

M. S., Aloliliweri. Gatra-Gatra Komunikasi Antar Budaya. Pustaka Pelajar: Yogyakarta. 2011.

Morissan, Andy Corry Wardhany. Teori Komunikasi. Ghalia Indonesia: Jakarta. 2009. 
Mulyana, Deddy. Metode Penelitian Kualitatif. Rosda Karya: Bandung. 2008.

Mulyana, Deddy \& Solatun. Metode Penelitian Komunikasi. Rosda Karya: Bandung. 2008.

Samovar, Larry A. Richard E. Porter. Edwin R. McDaniel. Komunikasi Lintas Budaya: Communication Between Cultures ed:7. Salemba Humanika: Jakarta. 2010.

Schutz, Alfred. On Phenomenology and Social Relation. Chicago: The University of Chicago Press. 1970.

Suseno, Frans Magnis. Etika Politik. Gramedia Pustaka Utama: Jakarta. 2003.

Soepandi B.A, Atik. Khasanah

Kesenian Daerah Jawa Barat.

Bandung : Pelita Masa. 1977

Thevenaz, Pierre. What is

Phenomenology?. Chicago:

Quadrangle Books. 1962. 